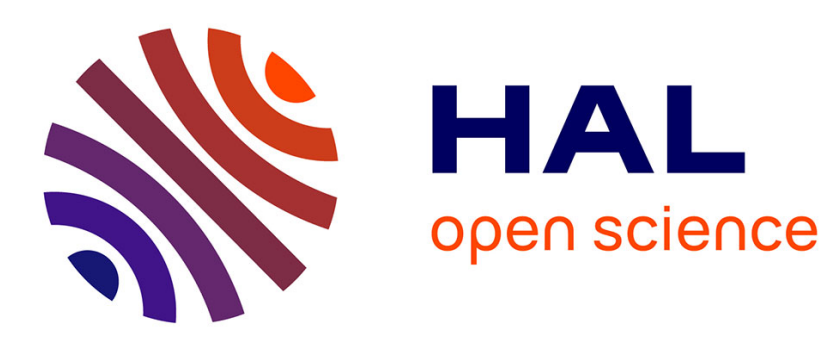

\title{
Karl Kleist and his refusal of an appointment at Leipzig in 1923
}

Holger Steinberg

\section{To cite this version:}

Holger Steinberg. Karl Kleist and his refusal of an appointment at Leipzig in 1923. History of Psychiatry, 2005, 16 (3), pp.333-343. 10.1177/0957154X05051629 . hal-00570822

\section{HAL Id: hal-00570822 \\ https://hal.science/hal-00570822}

Submitted on 1 Mar 2011

HAL is a multi-disciplinary open access archive for the deposit and dissemination of scientific research documents, whether they are published or not. The documents may come from teaching and research institutions in France or abroad, or from public or private research centers.
L'archive ouverte pluridisciplinaire $\mathbf{H A L}$, est destinée au dépôt et à la diffusion de documents scientifiques de niveau recherche, publiés ou non, émanant des établissements d'enseignement et de recherche français ou étrangers, des laboratoires publics ou privés. 


\title{
Karl Kleist and his refusal of an appointment at Leipzig in 1923
}

\author{
HOLGER STEINBERG* \\ University of Leipzig
}

\begin{abstract}
Further to the study by Neumärker and Bartsch (2003) of Karl Kleist (18791960), this short contribution based on archive material, cited for the first time, looks into Kleist's motives for refusing an appointment as Professor of Psychiatry and Neurology at Leipzig University. This study comes to the conclusion that Kleist thought seriously of moving to Leipzig. However, the Saxony Ministry of People's Education refused to make a definite financial commitment to the reconstruction and building work that Kleist considered essential. On the other hand, the authorities in Frankfurt am Main, where Kleist had been appointed 3 years earlier, evidently agreed to the funding he required if he was to remain there. This finally prompted him to turn down the Leipzig offer.
\end{abstract}

Keywords: biography; chair of psychiatry; history; institutions; Karl Kleist; Leipzig University; neuropsychiatry

$\mathrm{I}_{\mathrm{n}}$ 2003 History of Psychiatry published Neumärker and Bartsch's exemplary study intended to place Kleist's work within the context of neuroscientific history. The authors also briefly mentioned Kleist's proposed appointment in 1923 as Professor of Psychiatry and Neurology at Leipzig University - an offer which he eventually turned down. According to Neumärker and Bartsch (2003: 437), Kleist did not really consider the move to Leipzig as an interesting option; rather, he made use of it as a lever for achieving his goal, namely the granting of funds for the reconstruction of the old Klinik für Gemüts- und Nervenkranke (Hospital for the Emotionally and Nervously Ill) at Frankfurt University, of which he had been appointed head in 1920. This cannot be disproved and indeed there is evidence to substantiate it. However, Kleist, at least initially, considered a change to Leipzig as a possible and

\footnotetext{
* Address for correspondence: Archiv für Leipziger Psychiatriegeschichte, Klinik und Poliklinik für Psychiatrie, Universität Leipzig, Johannisallee 20, D-04317 Leipzig, Germany. Email: steinbh@ medizin.uni-leipzig.de
} 
realistic alternative to remaining in Frankfurt. This is convincingly revealed by investigation of the extensive and detailed correspondence Kleist had with the Leipzig Faculty of Medicine and the Saxony Ministry of People's Education; the letters are held in the Archives of Leipzig University (UAL) and the Saxony State Archives in Dresden (SächsHStA), respectively.

\section{The list of nominees}

By 1921 Paul Flechsig (1847-1929) had been Professor of Psychiatry at Leipzig University for 43 years and Director of the Psychiatrische und Nervenklinik (Hospital of Psychiatry and Neurology) for 38 years. His core interests, however, lay in the field of brain research and his own brainanatomical laboratory. Hence Oswald Bumke (1877-1950), a psychologically and philosophically orientated psychiatrist and neurologist, inherited a difficult mantle on being appointed Flechsig's successor in April of that year (Steinberg and Angermeyer, 2002: 270-6). ${ }^{1}$ Bumke represented nothing less than a total theoretical and practical change of course in Leipzig University's psychiatry. This was also shown in the organizational and architectural alterations introduced by Bumke, who had previously worked in Rostock. It seems, however, that Bumke was not completely satisfied with his work and administrative workload at Leipzig University, which kept him away from his current scientific and publishing interests. So Bumke soon started negotiations with the Bavarian authorities, as result of which he was finally appointed as Emil Kraepelin's (1856-1926) successor in the renowned Chair of Psychiatry in Munich and, ex officio, Director of the Nervenklinik in Munich's Nußbaumstraße. As early as the end of 1922 Bumke was determined to leave Leipzig, so the medical faculty had to make renewed efforts to find a replacement for the post.

The normal procedure was for the faculty to set up a special committee to compile a list of two, three or four potential candidates, with reasons for their choice. After making its decision, the committee had to report to the Faculty Council which in turn either approved the committee's proposals or made appropriate changes to the list. At the next meeting the Faculty Council then approved the official proposals initiated by the committee, and these were sent to the Saxony Ministry of People's Education in Dresden. Usually the Ministry confirmed the proposals the faculty had made and entered into negotiations with one of the proposed candidates, although this was not necessarily the candidate at the top of the list. If the first person contacted showed no real interest in the appointment or if the negotiations failed for some other reason, the Ministry usually approached one of the other candidates. However, it was common practice for the faculty to make preliminary contact with the candidates they considered suitable to see if they would accept their appointment should they be chosen. If they were not interested they were usually not included in the official list. 
As far as Bumke's successor in Leipzig is concerned, he could and did bring his influence to bear. In a letter to Karl Sudhoff (1853-1938), the world's first Professor of the History of Medicine, and at that time the Dean of the faculty of medicine, Bumke suggested that Kleist should be second on the official list. The latter was 44 years old, and had:

studied under Wernicke, ${ }^{2}$ Anton ${ }^{3}$ and Specht; ${ }^{4}$ succeeded me at Rostock and is now the head of the department of psychiatry at Frankfurt am Main. Without doubt he is an original and active researcher who has made an early name for himself with his book on the Psychomotoric Disturbances in Mentally Ill Patients, someone from whom we will surely expect very valuable contributions in the future. Sometimes Kleist's views are fiercely contested, although even his opponents cannot but acknowledge the originality of his works. Kleist has a very energetic, forceful, bright-eyed personality and is a most inspiring teacher. He had to face difficult circumstances in Frankfurt and would certainly accept an appointment at Leipzig. (UAL: 97, 09.07.1923)

In their list of nominees the faculty committee followed Bumke's suggestions and put forward Kleist, 'besides' Robert Gaupp (1870-1953), a student of Wernicke and Kraepelin and since 1906 head of the department of psychiatry at Tübingen University. They even used Bumke's wording regarding Kleist: 'of whom we deem to know that he would accept an appointment at Leipzig' (UAL: 94, 22.07.1923).

The medical faculty even put Kleist first in their final list of nominees sent to the Saxony Ministry in Dresden:

First and foremost Professor Kleist in Frankfurt am Main should be named here. The faculty is of the opinion that his appointment to the Chair at Leipzig would provide the best possible successor to our outgoing colleague Bumke. Kleist has universally been commended to us as one of the most capable and most competent of the younger generation of psychiatrists, from whom the discipline will certainly benefit in many ways ... He is as much an outstanding psychiatrist as a superbly qualified neurologist, who through his book on the psychomotoric disturbances in mentally ill patients had made an early name for himself. During the war he carried out valuable clinical and surgico-therapeutical research on war victims suffering from brain injuries. By all who know him he is considered as having a supremely fresh, exciting and likeable personality. $\mathrm{He}$ is an outstanding teacher, equally popular with students and assistants. (SächsHStA: 1-2; UAL: 113, 08.09.1923)

Convinced by these committed arguments, Senior Ministerial Councillor von Seydewitz, permanent head of a ministerial department, dispatched an official enquiry to Kleist dated 15 November 1923 asking whether he would be willing to enter negotiations about his appointment and, if so, whether he would be prepared to attend a meeting at the Minister's office (SächsHStA: 3). Three days earlier the Saxony Ministry had informed the Prussian 
Ministry for the Sciences, Arts and People's Education in Berlin of their intention to offer Kleist a professorship in Saxony, enquiring about Kleist's current salary as professor at Frankfurt University but also whether there were 'any special reservations' about him (SächsHStA: 4).

\section{The appointment negotiations: Kleist's conditions}

The anticipated answers were received from both nominees. In his letter of 20 November 1923, Kleist informed the Ministry: 'most assuredly I will be pleased to enter into negotiations as regards an appointment at Leipzig University as successor to Privy Councillor Professor Bumke'; he suggested a first meeting a fortnight later (SächsHStA: 5, 20.11.1923). The Berlin authorities informed their Saxony counterparts that 'the Prussian Educational Authority cannot raise any objections against the above-mentioned's appointment at Leipzig'. They did, however, 'intend to make efforts to ensure Kleist remains at Frankfurt University. Prof. Kleist's current basic salary is 1,960,000.-M' (SächsHStA: 7, 01.12.1923). On 2 December 1923 Kleist appeared at the Saxony Ministry of People's Education and in a personal presentation outlined his conditions and made quite specific demands. The sources imply that he had, perhaps the day before the meeting in Dresden, inspected the Leipzig Psychiatric and Neurological Hospital to get a firsthand impression of the conditions there. Of course he might also have received detailed indications as to what had to be done and changed. Senior Governmental Councillor Ulich summarized the discussion in the following memo:

Kl. has not yet made up his mind as to whether or not to accept the appointment, since there are certain circumstances that seem to make him inclined to remain at Frankfurt. He will be posting his demands to the Ministry. However, since he made a demand, among others, to have the psychiatric hospital rebuilt and extended, I made it clear to him right from the start that he could not rely on having his wishes fulfilled. Nor could he be allowed to hire new staff. (SächsHStA: 8)

The Saxony Ministry was obviously not willing to grant any major concessions. Some days later Kleist took the liberty of sending 'a list of wishes and suggestions which I presented during our discussion re my appointment'. This list, which was closely typed on five A4 sheets, seems to have been based on a rather good knowledge of the conditions at the Leipzig hospital. Furthermore, it suggested that Kleist had given thorough consideration to his possible work in Leipzig. First of all Kleist required 'construction works' which had already been promised to Bumke, such as the painting of walls and ceilings in several wards and departments (among them all the wards on the first floor) as well as the renewal of the exterior finish of the hospital building. Then followed requirements regarding visual, hygienic 
and therapeutic improvements in the ward with the long-term baths, for example, enamel coating of the bath-tubs, tiling of the walls and the fitting of electric fans. Moreover, Kleist required the bathroom and cloakroom in two wards to be enlarged, and the rest-rooms facing the garden in two wards to be developed as in the plans drawn up by Bumke. He also demanded a promise by the authorities that, as soon as the financial situation improved, one new building would be built for the outpatient department, as well as flats for the employees. He also outlined the requirement of building a new special ward for children, since:

children's guidance, academic tuition and research in the field of child psychopathology are priority tasks for a hospital, above all in a large city like Leipzig where, as in Frankfurt, Berlin, Vienna, Tübingen and other places, a separate department for mentally and nervously abnormal children should be set up. The rooms should ideally be located in the new outpatient department building, separated from the wards for the adult patients. For the time being, use could be made of a room in the wards, both the male and female, dedicated to non-violent patients.

Last but not least, Kleist demanded 'a ward for about 30 nervously ill and cerebrally affected patients, as I have here in Frankfurt, and to which, for scientific reasons, I attach greatest importance.' The establishment of this ward was also to be tackled as soon as funding allowed, perhaps by adding one more floor to the pavilions.

Thereafter Kleist continued with more modest demands regarding the facilities, fittings and equipment of the hospital building. First and foremost the internal telephone system should be thoroughly checked and repaired. Moreover, deckchairs for the patients' garden and the rest-rooms should be purchased, as well as a mobile stretcher for transporting patients, and teaching materials and games for the children's ward. Additionally, the hospital should be granted funds for maintaining an anatomy laboratory as well as a physiological and serological laboratory. As a concession Kleist expressed his readiness to bring a large section cutter and a camera together with a motion-picture projector and two large sun-lamps from Frankfurt, subject to the costs being refunded. Coming next to personnel matters, Kleist required two secretaries to be employed, one of whom he would like to bring from Frankfurt. He would also like to hire two kindergarten teachers and a laboratory assistant with special knowledge of histology. As regards the medical staff, Kleist wrote:

For the hospital's sake I urgently request senior medical officer Dr. Böttcher ${ }^{5}$ be transferred from the hospital to another post in a regional medical centre or to some other official position. It would also be much appreciated if Associate Professor Dr Pfeifer ${ }^{6}$ were relieved of the position of senior assistant, as I support his wish of being awarded a teaching assignment and appointment as Associate Professor of orthopaedic 
medicine. Replacement staff for these posts should be hired in line with my proposals.

Kleist also demanded responsibility for replacing the senior assistant, the assistant and the trainee doctor, who would be transferring to Munich with Bumke.

Next, Kleist expressed his views on the Director's lodging. He emphasized that in Frankfurt he was provided with a 'beautifully situated 10-room flat with siderooms and storerooms and a large kitchen as well as a fruit, vegetable and flower garden', continuing that in Leipzig 'similar accommodation should be provided'. Basically, he would be willing to accept the accommodation provided for Bumke, although it did not, as he pointed out, have a fruit and vegetable garden. However, the rent he was quoted seemed unacceptably high in comparison to what he would have to pay in Frankfurt. Kleist went into great detail about the rent and extra costs for the flat, above all for the heating. Reading between the lines, it becomes clear that Kleist had visited Bumke in Leipzig, where they had obviously also extensively discussed the question as to what could reasonably be demanded from the Ministry. ${ }^{7}$

The last point discussed by Kleist in his letter was the question of his salary. Since Germany was suffering from high inflation, he could not give a final figure. He would, however, expect a salary 'higher by a reasonable amount than my recent salary here', and he presumed that he would be compensated for any costs arising in connection with him and his family moving to Leipzig (SächsHStA: 9-11, 07.12.1923).

On behalf of the Minister, Senior Governmental Councillor Ulich wrote a very detailed answer to Kleist's demands. Basically, all requests concerning construction work and the purchase of equipment for the hospital would have to be postponed to a later date when budgetary funds would allow such major investments. On the other hand, less expensive or low-cost projects such as the establishment of a special ward for children or all requests concerning the laboratories could be carried out. However, hiring extra staff would be 'totally impossible'. He also informed Kleist that the Ministry would consider transferring Dr Böttcher to another post, but a transfer and promotion of Dr Pfeifer was unlikely. What is more, if Pfeifer and Böttcher were transferred elsewhere, Kleist would not be allowed to hire new staff to replace them. This would only be possible for the medical staff Bumke had already announced he would take with him, and the Ministry would of course be willing to take into account Kleist's views. As regards refunding of relocation expenses, they would only be granted to Kleist himself and not to other staff he might bring with him. Finally, Ulich told Kleist that as far as the salary was concerned the Ministry was thinking of the same amount as it had paid Bumke (SächsHStA: 12-14, 18, 28.12.1923/29.01.1924).

Despite this rather negative reply, it seems as if Kleist was tending towards acceptance of the appointment at Leipzig. This can be substantiated by a 
letter he wrote to Bumke. Kleist said that he regarded it an essential prerequisite for his accepting the appointment that he be allowed to take with him some of his Frankfurt staff ('die Mitnahme einiger hiesiger Herrn'), by which he meant physicians. As regards the two secretaries he had asked for, he wrote: 'I think I could get by with one shorthand typist'. Finally he enquired what salary Bumke currently received (UAL: 147, 12.02.1924).

Following their initial contact, Kleist sent further letters to the Ministry, in which both sides discussed more details (SächsHStA: 20-32). In the course of this correspondence the Ministry agreed to have at least the necessary paintwork done and guaranteed the funding for the laboratories. However, the other construction projects could be promised only for a later date. Furthermore, the Ministry conveyed the Leipzig Dean's wish that the negotiations should soon be completed. In his response of $16 \mathrm{March}$, Kleist said he felt 'embarrassed' to have to request 'several more days of patience' before the negotiations could be continued. He even gave the reason:

I am still awaiting information, which will however be delayed for some days as the head of the local [Frankfurt] municipal health authority is ill. As you will certainly appreciate, I cannot make a decision as difficult and irrevocable as the appointment at Leipzig without having discussed the matter with all parties. (SächsHStA: 25)

This message reveals that Kleist did not want to rule out the Leipzig option; he preferred, however, to remain at Frankfurt. Evidently the news from the Frankfurt authorities did not come up to his expectations. At any rate, he contacted the Saxony Ministry again on 27 March 1924 asking for a resumption of negotiations. As a result a joint inspection of the hospital was arranged for a fortnight later, 12 April, involving Kleist (who came to Leipzig specially for it), von Seydewitz, Ulich and several building experts. By this time some of the painting had already been finished. In his next letter Kleist again emphasized how important it was to establish a special ward for children. In its response dated 2 May 1924 the Ministry finally made more concessions to Kleist concerning personnel matters (permission to recruit another secretary and another laboratory assistant) as well as Kleist's salary (the Ministry was willing to pay a salary significantly higher than the one he was then getting in Frankfurt). Kleist was also informed that the Leipzig mayor had been contacted regarding his accommodation requirements.

\section{The decision}

Towards the end of May the Prussian Ministry and the Frankfurt city authorities $^{8}$ seem to have made even more concrete and far-reaching concessions to Kleist. This is indirectly implied in Kleist's letter to the Saxony Ministry (SächsHStA: 33, 26.05.1924). Having still not received a definite answer from Kleist, the latter increased the pressure, presumably because of 
demands made by the medical faculty of Leipzig University. Kleist was set a deadline: he had to make a decision by 7 June, i.e., within a fortnight, a request to which Kleist did not, however, agree. Although he sent a 3-page letter, he did not make a final decision, and attributed the delay to internal discussions between the authorities in Berlin and Frankfurt. He even challenged the Saxony Ministry's letter dated 2 May, which had in fact contained numerous concessions on the Ministry's part! He demanded guaranteed funding for the construction works to be carried out within the next few years. However, the text of the letter suggests that Kleist was still inclined to view a move to Leipzig as an interesting option:

After my last stay in Leipzig I was strongly inclined to accept the appointment; from the negotiations with you and Privy Councillor von Seydewitz I had no reason to doubt that my wishes would be fulfilled. On the other hand, I had the impression from my talks with the authorities in Frankfurt and Berlin that they could not hold out the prospect of anything comparable to the arrangements promised for Leipzig. Then however I received your letter of 2 May, which did not come up to my expectations and even left doubts regarding some details, though I do acknowledge the concessions you made in other respects. (SächsHStA: 36-7, 04.06.1924)

Although the Ministry's reply did not contain any binding financial commitments, it did reveal that the authority felt the funds Kleist had requested were totally justifiable, and once more it declared its willingness to grant the funds as soon as they were available. The Ministry merely qualified this by stating that some of these projects would have to be checked by experts first. Finally definite arrangements regarding his flat could only be made once Kleist had accepted his appointment (SächsHStA: 38-9, 12.06.1924). On 14 June Kleist contacted the Saxony Ministry again announcing that he was about to make a final decision and saying that the previous letter from the Ministry had 'extinguished all doubts I had had concerning the Leipzig department'. He just wanted to await the outcome of a visit of a delegation of the Frankfurt authorities to Berlin (SächsHStA: 40, 14.06.1924). Once more the medical faculty at Leipzig urged him to make a decision. Dean Ernst Hertel (1870-1943), Professor of Ophthalmology, enquired about the state of affairs at the Saxony Ministry (SächsHStA: 41, 20.06.1924). The next day, 21 June, in a telephone call to von Seydewitz, Hertel 'requested the Ministry on behalf of several members of the faculty to let Kleist know that the negotiations were regarded as having failed.' From the memorandum in question, however, it becomes clear that von Seydewitz succeeded in persuading Hertel to give Kleist two days' grace - a deadline which was to be transmitted to Kleist. This the Ministry did promptly (SächsHStA: 43, 21.06.1924).

Next, the Ministry received a telegram dated 23 June, reading 'Decline the 
appointment, letter to follow $=$ Kleist' (SächsHStA: 44, 23.06.1924). In the letter Kleist gave reasons for his refusal:

After the local authorities agreed to fulfil all the wishes which I had advanced from the very beginning as arguments for my turning down the Leipzig offer, I could not do anything other than what my cable message of today said. The importance of Leipzig University and the concessions made by your Ministry made it very difficult for me to decide as I did. You may remember from our negotiations during the Easter break how near I was to accepting your offer. I could not, and did not, hope for the decision that was finally made by the local authorities here, and this gave the matter a new turn. Once this decision was made, I felt obliged to my friends and the many supporters of our university and my department, who had initiated a considerable donation to the hospital. Furthermore there were scientific and personal reasons. In order to accomplish certain projects I would require a lot of brain pathological material of which there is plentiful supply here, but much less in Leipzig. Finally, it would not have been beneficial to my psychiatric research to move my job after just a few years, since with every move findings go missing and the long-term observations of the course of illnesses are seriously affected. Moreover, I admit freely that I feel totally at home here and I could not wish for a more healthy and beautiful home and lodging than here. I do regret very much that there has been such a delay as regards my decision in this matter. You will certainly remember from my letters that it was not entirely my fault. I feel depressed that I have caused so much trouble for you and all the other parties involved, troubles which in the end were not crowned by success. Despite this I dare to hope that the negotiations I led will make it easier to appoint someone else. (SächsHStA: 45, 23.06.1924)

\section{Kleist interferes}

The Saxony Ministry does not seem to have been too upset by this refusal. When the Leipzig medical faculty handed in another list of nominees, which was not decided on unanimously, Kleist was asked for his opinion. Two potential candidates were put forward. The first, proposed by the faculty in their official letter, was Georg Stertz (1878-1959) of Marburg, who was supported by Specht, Hoche ${ }^{9}$ and also by Bumke (who had been Stertz's head at Breslau). The second candidate, put forward by opponents within the Leipzig faculty who did not feel bound by the official proposal, was Paul Schröder (1873-1941) of Greifswald (SächsHStA: 47-51, 25./30.07.1924). When Kleist was asked with whom the Ministry should negotiate, he replied that 'I am convinced that Schroeder-Greifswald should be given preference for the Leipzig chair over Stertz-Marburg' (original emphasis) - a view that matched the opinion of Karl Bonhoeffer (1868-1948), head of the department of psychiatry at the Charité in Berlin, und Flechsig (SächsHStA: 53). Kleist thus influenced the course of affairs in the department of 
psychiatry at Leipzig, as the Ministry then contacted Schröder and appointed him as Bumke's successor in the spring of 1925 (Steinberg and Angermeyer, 2002: 276-7). Kleist had written to the Leipzig faculty: 'I am glad I could at least be of some help with the proposals as to whom to appoint and I do hope that you will succeed in finding a successor for Flechsig and Bumke worthy of the Leipzig chair.' (UAL: 127, 13.07.1924). This wish was to be fulfilled. Under Schröder's guidance the Leipzig department became one of the leading German institutions and proved to be a Europe-wide leader in the field of child and adolescent psychiatry.

\section{Acknowledgements}

The author wishes to thank Dirk Carius of Sächsische Sprachendienste Leipzig (d_carius@web.de) and Graham Evans (London) for translating and editing his paper.

\section{Notes}

1. Interestingly, Leipzig's Medical Faculty had already included Kleist on the list of possible candidates for Flechsig's succession; the list had been passed to the Saxony Ministry of People's Education in 1920-21 (UAL: 94b).

2. Carl Wernicke (1848-1905) worked as Professor of Psychiatry and Neurology and was head of the department of psychiatry at Breslau University; he described sensory aphasia, did research in brain localization and the psychological interpretation of brain anomalies.

3. Gabriel Anton (1858-1933) was head of the department of psychiatry and neurology at Graz University, and also worked in Dobrzan, Prague, Vienna, Innsbruck and Halle; he did research mainly in anatomical brain pathology and the perceptive and motor disturbances that ensued from it.

4. Gustav Specht (1860-1940) was Professor of Psychiatry and head of the department at Erlangen; he did research in psychogenic disturbances as a result of war and in the psychopathology of the autonomic nervous system

5. Wilhelm Böttcher was, from 1913, senior assistant or second doctor, i.e., deputy head of the Leipzig department of psychiatry. He was going to retire on 1 April 1924 (SächsHStA: 20).

6. For more research on Richard Arwed Pfeifer (1877-1957), see Steinberg \& Angermeyer, 2002: 276-9.

7. See Kleist's letter to Bumke: 'The improvements as regards the long-term baths, the cloakrooms, rest-rooms, the outpatient department and the building for hospital flats, as suggested by you, have been turned down.' (UAL: 147, 12.02.1924).

8. According to the Statutes of Frankfurt University the following were involved in all decisions: the Prussian Ministry in Berlin, the Frankfurt city authorities and a board of trustees.

9. Alfred Erich Hoche (1865-1943) was, from 1902, Professor of Psychiatry and Neurology and head of the department at Freiburg/Breisgau University. He first did anatomical research and worked on pathological anatomy, and later devoted himself to forensic psychiatry. In 1920, with the Leipzig Professor of Law Karl Binding (1841-1920), he wrote a heinous book (Binding and Hoche, 1920), later published in English as The Release of the Destruction of Life Devoid of Value. Its Measure and Forms (1975). This was to pave the way for the killing of mentally ill patients during the Nazi fascist period. 


\section{References}

Binding, K and Hoche, A. (1920) Die Freigabe der Vernichtung lebensunwerten Lebens. Ihr Maß und ihre Formen (Leipzig: Meiner); also published in English: The Release of the Destruction of Life Devoid of Value. Its Measure and Forms (Santa Ana, CA, 1975).

Neumärker, K.-J. and Bartsch, A. J. (2003) Karl Kleist (1879-1960) - a pioneer of neuropsychiatry. History of Psychiatry, 14 (4), 411-58.

SächsHStA: Sächsisches Hauptstaatsarchiv Dresden. Ministerium für Volksbildung, 10281/ 272.

Steinberg, H. and Angermeyer, M. C. (2002) Two hundred years of psychiatry at Leipzig University: an overview. History of Psychiatry, 13 (3), 267-83.

UAL: Universitätsarchiv Leipzig. Medizinische Fakultät, B III 19 vol. 1. 